\title{
Ecosystem Assessment of Island Based on PSR Model - A Case Study of Zhou Shan Archipelago in China
}

\author{
Degang Wang, Gang Shen, and Yonghua Tan
}

\begin{abstract}
The paper studied the change tendency of Zhou Shan Archipelago ecosystem by Pressure-State-Response (PSR) model based on the 2006-2015 Statistical Yearbooks of the study site. The paper constructs an index system used to evaluate this island ecosystem that covers the aspects of the social economy, environmental quality and ecology. Then, correlation theory analysis was used to study the main factors that affect the status of the Zhou Shan Archipelago ecosystem. The results revealed worrisome concerns related to the ecological status of the Zhou Shan Archipelago. The main concerns are generated by increased pressure from industrial wastewater discharge, emissions of pollutants into the sea and the level of economic development.
\end{abstract}

Index Terms-Islands ecosystem, PSR model, Zhou Shan archipelago.

\section{INTRODUCTION}

Islands provide important parts of any nation's territory and typically have high economic and national defense values However, island ecosystems are often very fragile and susceptible to damage by human activities and disturbance. With the intensification of activities related to the exploitation of island ecosystems, conflicts between human needs and the environment continue to increase. This generates a need to enhance the conservation and management of islands and their resources. Conservation and management of islands should be based on the nature of the island ecosystem. Meanwhile conducting an ecosystem assessment of islands is the foundation of the ecological planning, development and management of islands.

MacArthur (1963) proposed "the geography balance theory of island animals" and published the "island biogeography theory" which can be considered the beginning of island ecosystem research [1]. Since 1992, scholars from different countries have conducted research and evaluated island ecosystems from various angles while using various means to solve outstanding problems related to the both the degradation and reasonable management of island ecology. Harding et al. (1997) used GIS technology to classify the ecological region of the South Island in New Zealand [2]. Hill et al. (1998) monitored environmental changes of the Mediterranean Crete ecosystem by satellite remote sensing [3]. Gourbesville (2000) used Mayotte as an example of a sustainable water resource management approach for tropical

Manuscrpt received November 21, 2016; revised May 1, 2017

The authors are with the Second Institute of Oceanography, SOA, Hangzhou, 310012, China (e-mail: degang_w@sio.org.cn, hzshengang@163.com,tan_yh@126.com). island environmental assessment procedures [4]. Dimitra et al. (2002) proposed a method for multidimensional assessment and classification of coastal areas based on multi-layer criteria selection and GIS technology [5]. Smith (2003) developed a study of ecosystem pollution and restoration of Deption Island in Antarctica [6]. Ramjeawon (2004) conducted an environmental impact assessment and developed an environmental monitoring program framework for Mauritian Island [7]. David et al. (2005) developed a methodological framework for risk assessment of island wetland ecosystems based on the theoretical island biogeography and landscape ecology [8].

In the aforementioned studies, the United Nations Commission on Sustainable Development provided the "Pressure-State-Response" (PSR) model which focused on integrating the environmental impacts caused by human activities and developed these into a framework of indicators, greatly contributing to the global assessment of ecosystems. Guo et al. (2004) established a PSR-based land quality indicator system to reflect the causal relationship between changes in land quality more clearly, that will help decision-makers to adopt appropriate land management policies and measures for the rehabilitation of degraded land [9]. Li et al. (2005) combined the conceptual framework of PSR to study the connotation of sustainable development of small towns, and established an index system of sustainable development for small cities and towns. Based on the analysis of the indices, $\mathrm{Li}$ et al. proposed strategic recommendations in support of the sustainable development of small cities and towns [10]. Mai et al. (2005) analyzed the role of PSR model in wetland ecosystem health assessment, and based on this, proposed an index system for use during wetland ecosystem health assessment [11].

Using the Zhou Shan Archipelago in China as an example, the objective of the present paper was to establish an assessment indicator system for island ecosystems based on a "Pressure-State-Response" (PSR) model, and to analyze the status, change tendencies and management strategies of an island ecosystem.

\section{STUDY AREA}

The Zhou Shan Archipelago in Zhejiang Province and on the southeastern coast of China, lies south of the Yangtze estuary and on the outer rim of Hangzhou Bay (Fig. 1). The City of Zhou Shan is the only city of the island's regional administrative districts and is composed of 1390 islands, and includes one fifth of China's islands. The city has a total area of $2.22 \mathrm{~km}^{2}$, including sea area of $2.08 \mathrm{~km}^{2}$, stacking area 
$1440 \mathrm{~km}^{2}$. According to archaeological discoveries, the Zhou Shan Islands were inhabited by humans as early as 5000 years ago, in the Neolithic age.

The East China Sea surrounds the Zhou Shan Islands. These islands rise north of the southern tropical monsoon maritime climate and experience warm winters and cool summers that provide a moderately moist climate with sufficient sun-light. The islands have three advantages, including having a deep water harbor, providing tourist attractions and having the East of China Sea fish warehouse. On March 14, 2011, Zhou Shan Islands were included in the new national formal planning system aimed at making Singapore and Hong Kong world first-class port cities, with the goal of stimulating the economy of the entire Yangtze River Basin.

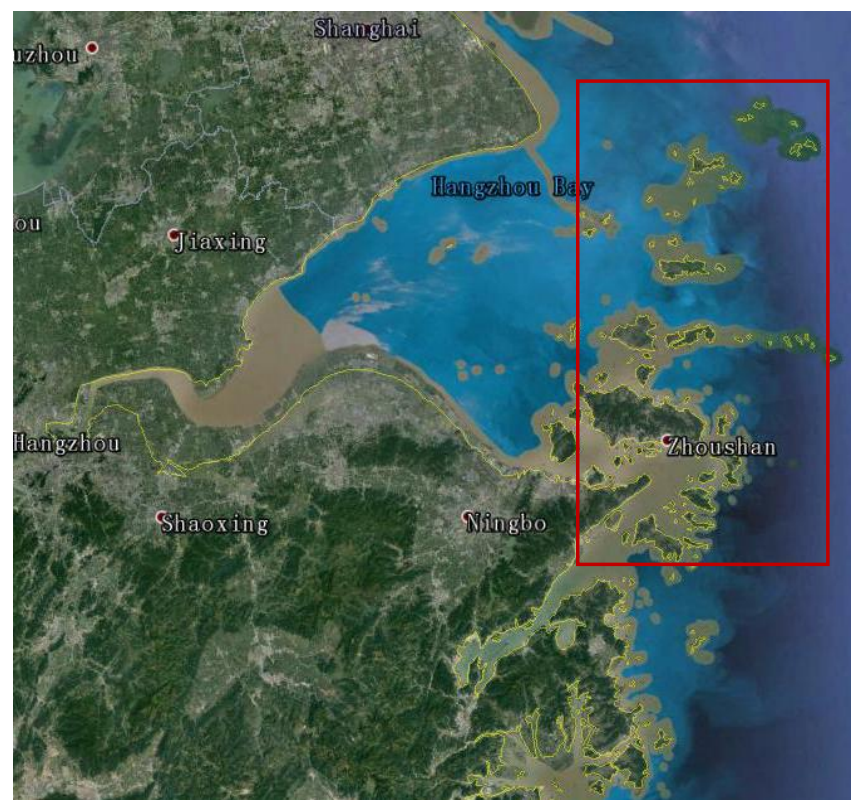

Fig. 1. Location of Zhou shan Archipelago (Inside the red box).

\section{DATA SOURCES AND METHODS}

\section{A. Data Sources}

The data sources include the followings 2006-2015 Zhou Shan Statistical Yearbooks, Zhou Shan Statistical Reports on National Economic and Social Development, and Zhou Shan Marine Environmental Bulletins, as well as the 2006-2015 Zhou Shan Environmental Quality Bulletins.

\section{B. Methods}

\section{1) PSR model principle}

In this paper, an environmental PSR model is used as the main method to evaluate an island ecosystem. The Pressure-State-Response (PSR) model was first proposed by two Canadian statisticians, Rapport and Friend (1979). The model was developed by the Organization for Economic Cooperation and Development and the United Nations Environment Program for use in studying environmental problems [12]. The model is based on a causal relationship between human activities that create stress on the environments and changes in the amount and status of natural resources caused by human activities. A PSR model reveals a linear relationship between human activity and the environment that best reflects the indicators between the causal relationships (Fig. 2).

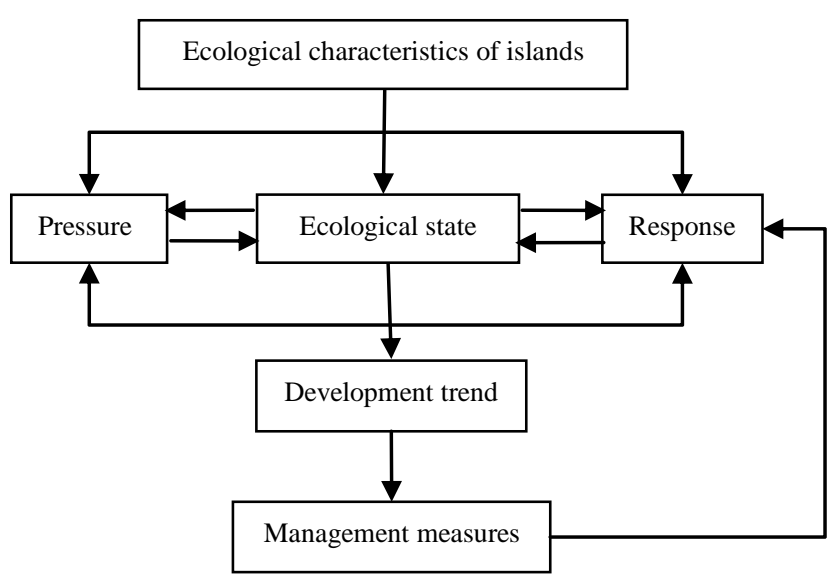

Fig. 2. Schematic diagram of island ecological assessment based on Pressure-State-Response Model.

\section{2) Selection of research indicators}

Based on the characteristics of the socio-economic and environmental conditions, this paper selects multiple indicators to serve as a complete indicator system for the health assessment of the Zhou Shan Island ecosystem. TABLE I shows the health assessment criteria of island ecosystem. In the present study, the combination of the annual and growth rate of the gross domestic product (GDP) along with household population density was selected as the driving force index. The total amount of wastewater discharge, Chemical Oxygen Demand (COD) emission and nutrient salt discharge were selected as indices of the pressure layer. The current state is the result of pressure, and constitutes the most direct causal relationship with pressure, and reducing pressure is also the ultimate goal of policy response. This assessment of the Zhou Shan Island ecosystems is based on the consideration of environmental quality and ecology. The relationship between water pollution, the pressure on the ecosystem and response of urbanization is quantitatively studied using correlation analysis.

TABLE I: HEALTH ASSESSMENT CRITERIA OF ISLAND ECOSYSTEM

\begin{tabular}{|c|c|c|c|c|c|c|}
\hline & $\begin{array}{c}\text { Indicator } \\
\text { level }\end{array}$ & $\begin{array}{c}\text { Collaps } \\
\mathrm{e}\end{array}$ & $\begin{array}{c}\text { Unheal } \\
\text { thy }\end{array}$ & $\begin{array}{c}\text { Sub } \\
\text { healt } \\
\mathrm{h}\end{array}$ & $\begin{array}{c}\text { Healt } \\
\mathrm{h}\end{array}$ & $\begin{array}{c}\text { Very } \\
\text { healt } \\
\text { hy }\end{array}$ \\
\hline \multirow{4}{*}{$\begin{array}{c}\text { Environme } \\
\text { ntal } \\
\text { Quality }\end{array}$} & $\begin{array}{c}\text { Surface } \\
\text { water } \\
\text { comprehens } \\
\text { ive index }\end{array}$ & $>1.25$ & $\begin{array}{c}1.25-1 \\
0\end{array}$ & $\begin{array}{c}1.0-0 \\
.75\end{array}$ & $\begin{array}{c}0.75- \\
0.5\end{array}$ & $\begin{array}{c}< \\
0.5\end{array}$ \\
\hline & $\begin{array}{c}\text { Eutrophicat } \\
\text { ion index of } \\
\text { waters }\end{array}$ & $>1$ & $\begin{array}{c}1.0-0.7 \\
5\end{array}$ & $\begin{array}{c}0.75- \\
0.50\end{array}$ & $\begin{array}{c}0.50- \\
0.25\end{array}$ & $\begin{array}{c}0.25- \\
0\end{array}$ \\
\hline & $\begin{array}{c}\text { Sedimentar } \\
\text { y } \\
\text { comprehens } \\
\text { ive index }\end{array}$ & $>1.25$ & $\begin{array}{c}1.25-1 \\
0\end{array}$ & $\begin{array}{c}1.0-0 \\
.75\end{array}$ & $\begin{array}{c}0.75- \\
0.5\end{array}$ & $\begin{array}{c}< \\
0.5\end{array}$ \\
\hline & $\begin{array}{l}\text { Comprehen } \\
\text { sive Index } \\
\text { of Heavy } \\
\text { Metals in } \\
\text { Shellfish }\end{array}$ & $>1.25$ & $\begin{array}{c}1.25-1 \\
0\end{array}$ & $\begin{array}{c}1.0-0 \\
.75\end{array}$ & $\begin{array}{c}0.75- \\
0.5\end{array}$ & $\begin{array}{c}< \\
0.5\end{array}$ \\
\hline $\begin{array}{l}\text { Biological } \\
\text { ecology }\end{array}$ & $\begin{array}{l}\text { Vegetation } \\
\text { coverage }\end{array}$ & $<10$ & $10-30$ & $\begin{array}{c}30-5 \\
0\end{array}$ & $\begin{array}{c}50-7 \\
0\end{array}$ & $>70$ \\
\hline
\end{tabular}




\begin{tabular}{|c|c|c|c|c|c|}
\hline $\begin{array}{l}\text { Chlorophyll } \\
\text { a content }\end{array}$ & $\begin{array}{l}<1 \text { or } \\
>5\end{array}$ & $\begin{array}{c}1-1.5 \\
\text { or5-4.5 }\end{array}$ & $\begin{array}{c}1.5-2 \\
\text { or } \\
4.5-4 \\
.0\end{array}$ & $\begin{array}{c}2-2.5 \\
\text { or } \\
4-3.5\end{array}$ & $\begin{array}{c}2.5-3 \\
.5\end{array}$ \\
\hline $\begin{array}{c}\text { Intertidal } \\
\text { zone } \\
\text { benthic } \\
\text { species } \\
\text { number } \\
\text { change rate }\end{array}$ & $>50$ & $50-40$ & $\begin{array}{c}40-3 \\
0\end{array}$ & $\begin{array}{c}30-2 \\
0\end{array}$ & $<20$ \\
\hline $\begin{array}{l}\text { Key species } \\
\text { reduction } \\
\text { rate }\end{array}$ & $>10$ & $10-7.5$ & $\begin{array}{c}7.5-5 \\
.0\end{array}$ & $\begin{array}{l}5.0-2 \\
.5\end{array}$ & $\begin{array}{c}< \\
2.5\end{array}$ \\
\hline
\end{tabular}

\section{3) Weight determination of the evaluation index}

The subjective weighting method employs expert advice. The paper quotes preliminary results of the "Chinese Island Ecosystem Assessment (No. 908-02-04-08)" from Chen et al [13]. In the period from May to October in 2006, 51 experts in the fields of Chinese oceanography, environmental science, and ecology were assigned to respond to a Questionnaire titled "Weight of Indicators for Island Ecosystem Assessment." TABLE II shows the subjective weights of island ecosystem assessment indicators.

TABLE II: SUBJECTIVE WeIGHTS OF THE ZHOU SHAN ISLAND ECOSYSTEM ASSESSMENT INDICATORS

\begin{tabular}{|c|c|c|}
\hline $\begin{array}{l}\text { First level } \\
\text { indicator }\end{array}$ & Secondary indicators & Weights \\
\hline \multirow{7}{*}{$\begin{array}{c}\text { Environmenta } \\
1 \text { Quality }\end{array}$} & & 4.25 \\
\hline & Quality of sea water environment & 2.07 \\
\hline & Quality of freshwater environment & 1.76 \\
\hline & Soil Environmental Quality & 1.46 \\
\hline & Sediment quality & 1.24 \\
\hline & Biological quality & 1.56 \\
\hline & Quality of habitat & 1.91 \\
\hline \multirow{6}{*}{$\begin{array}{l}\text { Biological } \\
\text { ecology }\end{array}$} & & 3.36 \\
\hline & Island land biological status & 2.55 \\
\hline & Intertidal biological status & 2.23 \\
\hline & Biological ecology of coastal waters & 1.85 \\
\hline & Rare species status & 1.89 \\
\hline & Alien species invasion status & 1.49 \\
\hline
\end{tabular}

\section{RESULTS AND ANALYSIS}

\section{A. Driving Force and Pressure Analysis}

As a driving force in the $21^{\text {st }}$ century, the growth rate of GDP and industrial output on Zhou Shan Island remained at an average of $10 \%$ or more, with the size of the continuous expansion of the economy of Zhou Shan Island leading to a new peak. The GDP of Zhou Shan reached 109.5 billion Yuan in 2015, an increase of 3.2 times that in 2006 (Fig. 3, Fig. 4). At the same time, the population of Zhou Shan Island continued to grow, although the overall increase in population density remains unclear (Fig. 5). However, with the strategy for the development of Zhou Shan, more and more farmers from the island migrated to the city in 2009. About 76,000 people moved to cities and the big Island which increased the population density of the local area of the island. The fifth population resource survey of 2000 stated the resident population was 1 million. Based on the sixth population resource survey in 2010, the resident population stood at 1.12 million.

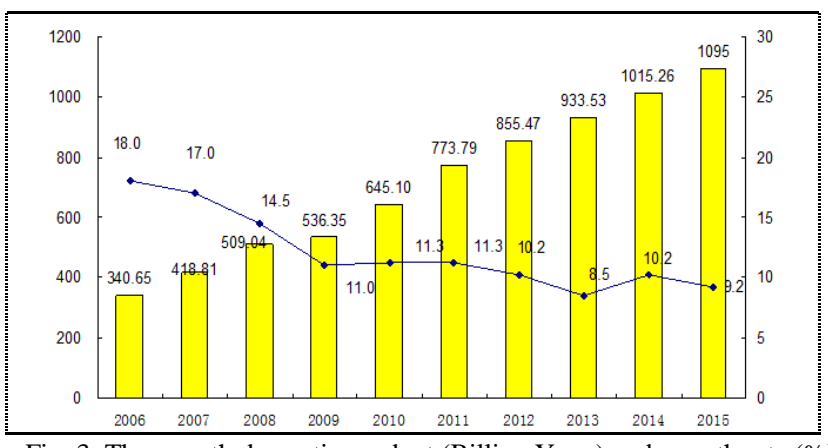

Fig. 3. The growth domestic product (Billion Yuan) and growth rate (\%) of Zhou Shan between 2006-2015.

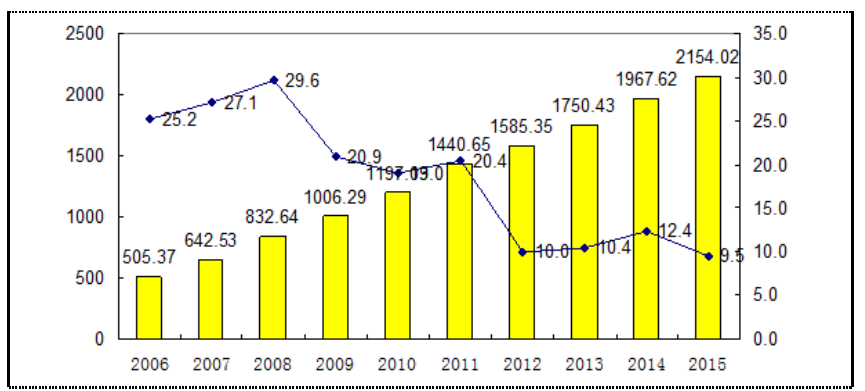

Fig. 4. The industrial OUTPUT (Billion) and growth RATE (\%) of Zhou shan between 2006-2015.

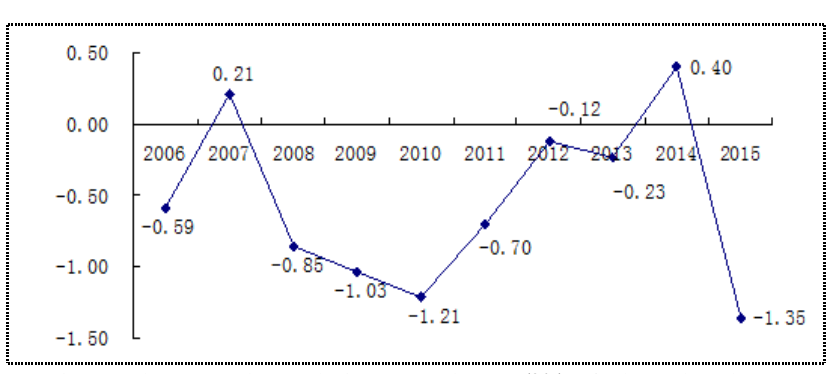

Fig. 5. The natural population growth rate (\%) of Zhou shan between 2006-2015.

The degree of human disturbance directly affects the island's ecological health also increases pressure with a driving force. With the recent rapid development of the urban economy and the related population growth, the sewage discharge quantity has been increasing unceasingly. In 2006, the wastewater discharge capacity of Zhou Shan was 27.05 million tons which increased to 73.91 million tons by 2015 .

These results indicate that the increase of the driving force behind pollution directly leads to an increase in pressure on the ecosystem. In order to further illustrate the correlation between the two, this paper analyzed how the driving force changes with changes in the quality of the sea water. The Pearson correlation coefficient calculated by SPSS13.0 software was used to measure the degree of closeness between the two variables, driving force and pressure. A larger correlation coefficient indicates a stronger correlation. The correlation coefficient $P$ is between $[-1,1]$. When the correlation coefficient $P$ is positive, this indicates that the variable " $A$ " increases with an increase of the variable " $B$." When the correlation coefficient $P$ is negative, this indicates that the variable " $A$ " increases when the variable " $B$ " decreases.

The results of the correlation analysis showed that household density was not positively correlated with other indicators. This occurred because Zhou Shan Island features 
unique characteristics in the distribution of the human population, such as an uneven distribution of the population, with the population and resources concentrated in the islands (Zhou Shan Island, including Zhujiajian Island), two counties (Daishan County seat in Daishan Island and Shengsi County seat in Shengsi Island) and three other large islands, specifically, Jintang, Liuheng, and Qushan. Household density did not change significantly between 2006 and 2015 . The $P$ value of industrial wastewater discharge and GDP is 0.895 , indicating that to some extent the value of industrial output is connected to the production of industrial sewage. During 2006-2015, Zhou Shan City wastewater emissions increased 2.7 times with the GDP increasing 1.5 times since 2006. The discharge of wastewater in Zhou Shan city mainly comes from industrial sources, and the fact that the $P$ value (0.895) of industrial wastewater is higher than that of domestic sewage (0.704) also reflects this situation (TABLE III).

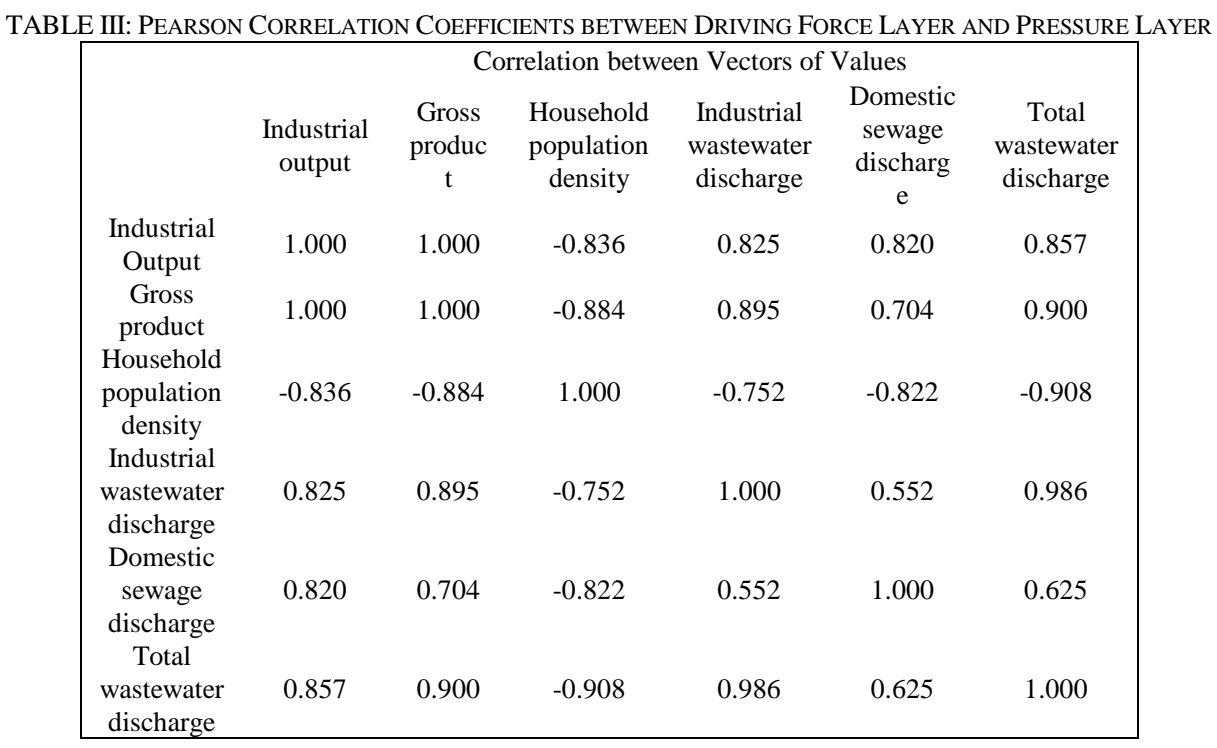

\section{B. Pressure and State Analysis}

The state of an island ecosystem is a comprehensive reflection of the coupling of various ecological and environmental factors, which is the final result of pressure. The pressure and the state constitute a most direct causal relationship, but managing that relationship is also the ultimate goal of policy responses. In order to further illustrate the correlation between the two, this paper uses the following case: How pressure changes the state of the sea water in the analysis.

This study analyzed the nature of pollutants of the Yangtze, Qiantang and Yongjiang rivers that influenced the environment of Zhou Shan (Table IV). In 2006, the waters of the Zhou Shan sea area were seriously, moderately and lightly polluted from west to east. The water quality of the Zhou Shan sea area was seriously polluted, and the intensity of the pollution gradually declined from west to east, reflecting the fact that the Yangtze, Qiantang, Yongjiang and other rivers provide the main sources of the pollution. During the past 10 years, emissions of major pollutants have been increasing, and the nutrient salt emissions have become very large. In 2007, 1.3 million tons of various nutrients including those in sewage were discharged and 19.31 million tons of ammonia nitrogen were discharged in 2015. This indicates that the health of the Zhou Shan Island ecosystem is not only affected by the production and the level of economic development, but also by the sewage discharged near the sea.

Impacts can reflect improvements or deterioration of the state of the ecosystem. The deterioration in the health of the Zhou Shan Island ecosystem will have a strong negative impact on social production and public life. Based on the Zhou Shan Marine Environment Bulletin (2006-2015), the occurrence of red tides in Zhou Shan has had no obvious decreasing trend, and the range of fluctuation range of the affected area is also very large. In 2007, 17 red tides occurred, ranking first in the history of red tide frequency. These findings have fully proven that the environment in Zhou Shan continues to deteriorate, but also serves to remind land and aquatic resource managers that greater efforts are needed related to ecological and environmental protection.

TABLE IV: THE QUALITY OF SEAWATER IN ZHOU SHAN OFFSHORE BETWEEN 2007-2014

\begin{tabular}{cccccc}
\hline Quality & $\begin{array}{c}\text { A level of } \\
\text { seawater } \\
(\%)\end{array}$ & $\begin{array}{c}\text { B level of } \\
\text { seawater } \\
(\%)\end{array}$ & $\begin{array}{c}\text { C level of } \\
\text { seawater } \\
(\%)\end{array}$ & $\begin{array}{c}\text { D level of } \\
\text { seawater } \\
(\%)\end{array}$ & $\begin{array}{c}\text { Inferior } \\
\text { seawater } \\
(\%)\end{array}$ \\
\hline 2007 & 5.3 & 10.5 & 10.5 & 15.8 & 57.9 \\
\hline 2008 & 15.8 & 15.8 & 10.5 & 21.1 & 36.8 \\
\hline 2009 & 15.8 & 10.5 & 10.5 & 10.5 & 52.7 \\
\hline 2010 & 0 & 10.5 & 10.5 & 15.8 & 63.2 \\
\hline 2011 & 17.0 & 17.0 & 4.4 & 11.0 & 50.6 \\
\hline 2012 & 25.2 & 13.2 & 4.4 & 4.4 & 52.8 \\
\hline 2013 & 20.8 & 8.8 & 4.4 & 8.8 & 57.2 \\
\hline 2014 & 12.6 & 8.2 & 4.4 & 17.6 & 57.2 \\
\hline
\end{tabular}

\section{CONCLUSIONS AND RECOMMENDATIONS}

\section{A. Conclusions}

This study employed correlation analysis to analyze the local trends and evolution mechanism of ecosystem health, especially as it is related to the quality of the aquatic environment in the Zhou Shan Archipelago, under the 
influence of external driving forces, pressures and responses. The results show that a dynamic causal relationship exists between the driving forces, pressures, and the state and response of the Zhou Shan Archipelago ecosystem. An increase in the driving force leads directly to the enhancement of pressure on the ecosystem, and a direct increase or reverse in the change of pressure directly leads to a change of the state of the ecosystem. The "Pressure - state - response" between the three interacts and they influence each other; the causal relationship is obvious and sensitive.

\section{B. Recommendations}

In this evaluation of this island ecosystem, the quantitative evaluation method of stress and response of island ecosystem should be further explored, and quantitative relationship between pressure, state and response should be analyzed. This should lead to the establishment of a more perfect evaluation system of ecosystem pressure, state and response, to obtain more scientific research and evaluation results.

The assessment of island or ocean ecosystem involves a long-term process. Because of changes in the natural environment and human activities, the nature of the interference occurring in an island/ocean ecosystem is constantly changing. Therefore, long-term monitoring of the island/ocean ecosystem needs to be conducted.

Although the present situation of the Zhou Shan Archipelago was evaluated in this study, due to the lack of historical data, it is not possible to conduct a more in-depth evaluation of the process of change in this island ecosystem. In the future, expanding the time scale can be considered as part of an effort to carry on the long-term continuous monitoring to the Zhou Shan Archipelago ecosystem. At the same time, researchers should retrospectively evaluate the ecosystem and conduct an environmental impact assessment to fully reflect the ecological dynamics of the islands.

\section{ACKNOWLEDGMENTS}

The Zhejiang Provincial Natural Science Foundation of China (Grant No. LY15D060003) and the Scientific Research Fund of the Second Institute of Oceanography, SOA (Grant No. JT1204) supported this research.

\section{REFERENCES}

[1] R. H. MacArthur and E. O. Wilson, "An equilibrium theory of insular zoogeography," Evolution, vol. 17, pp. 373-387, 1963.

[2] J. S. Harding and M. J. Winterbourn, "An ecoregion classification of the south Island New Zealand," Journal of Environmental Management, vol. 51, pp. 275-287, 1997.

[3] J. Hill, P. Hostest, and G. Tsiourlis, "Monitoring 20 years of increased grazing impact on the Greek island of Grete with earth observation satelites," Journal of Arid Envi-ronments, vol. 39, pp. 165-178,1998.

[4] P. Gourbesville and B. Thomassin, "Coastal environment assessment procedure for sustainable wastewater management in tropical islands the Mayotte example," Ocean and Coastal Management, vol. 43, pp. 997-1014, 2000

[5] D. Kitsiou, H. Coccossis, and M. Karydis, "Multi-dimensional evaluation and ranking of coastal areas using GIS and multiple criteria choice methods," The Science of the Total Environment, vol. 284, pp. $1-7,2002$.

[6] K. Smith and R. Baldwin, "Ecosystem studies at deception Island, antarctica: An over-view," Deep-Sea Research, vol. 50, pp. 1595-1609, 2003.
[7] T. Ramjeawon and R. Beedassy, "Evaluation of the EIA system on the Island of Mauritius and development of an environmental monitoring plan framework," Environmental Impact Assessment Review, vol. 24, pp. 537-549, 2004.

[8] David G. Angeler and M. A. Cobelas, "Island biogeography and landscape strucure:Integrating ecological concepts in a landscape perspective of anthropogenic impacts in temporary wetlands," Envirommental Pollution, vol. 138, pp. 420-424, 2005.

[9] X. D. Guo, Y. Qiu, and G. Lian, "Land quality indictors based on 'Press-State-Response' framework at catchment for soil degradation by water erosion," Acta Ecologica Sinica, vol. 24, pp. 1884-1894, 2004.

[10] X. H. Li and K. Hen, "Tactics of sustainable development of little-size town based on the conceptual frame of PSR," Journal of Sheny ang Jian Zhu Univer-Sity.(Social Science), vol. 7, pp. 48-51, 2005.

[11] S. O. Mai, S. J. Xu, and Y. J. Pan, "Application of the PSR model to the evaluation of wetland ecosystem health," Tropical Geography, vol. 25, pp. 317-321, 2005.

[12] Organization for Economic Cooperation and Development (OECD).OECD Environ-mental Indicators: Development Measurement and Use. [Online]. Available: http://www.oecd.org/dataoecd/7/47/24993546.pdf

[13] B. Chen and W. W. Yu, "Discussion on integrated assessment method of Island," Journal of Applied Oceanography (TAI WAN HAI XIA), vol. 25, pp. 566-571, 2006

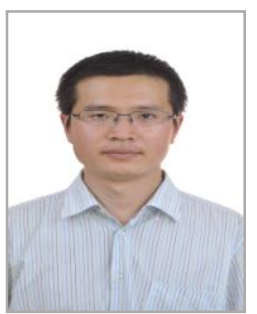

Degang Wang was born in Shandong province, China. He received a M.S. degree in marine geology from Second Institute of Oceanography in 2008 Now, Dr. Wang is associate professor of State Research Centre for Island Exploitation and Management at Second Institute of Oceanography, SOA.

$\mathrm{He}$ has been active in the area of Island development, protection and management for nearly 10 years and has been a frequent contributor to Zhejiang Ocean and Fishery Bureau. His current research involves study of ecosystem services and of land use change influence mechanism on ecosystem service values, support for the scientific development of the island in China.

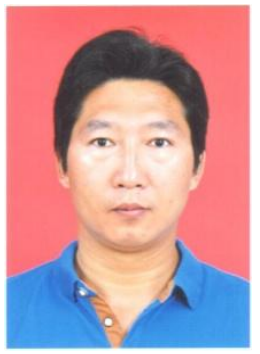

Gang Shen was born in Hubei province, China, in 1978. He received the Ph.D. degree in agricultural environment engineering from Tokyo University of Agriculture and Technology, Japan, in 2011. His major field of study is landscape ecology and sea-island conservation and management.

In 2013, he joined Second Institute of Oceanography, State Oceanic Administration, China. His current research interests include landscape changes and ecological processes of islands and coastal zones, ecosystem health and integrity of islands and coastal zones, environmental monitoring and dynamic modeling of islands and coastal zones.

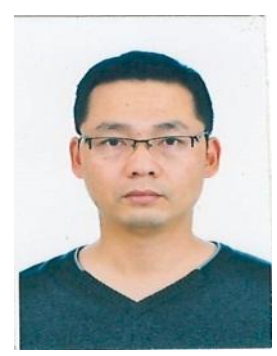

Yonghua Tan was born in Hubei province, China, in 1977. He received the master's degree in marine geology from Second Institute of Oceanography in 2008 .

In 2003, he joined Second Institute of Oceanography. Now, he is associate professor of State Research Centre for Island Exploitation and Management at Second Institute of Oceanography, SOA. His current research interests include ecosystem health, ecological protection and remediation of islands. 